\title{
Does Guided Inquiry enhance learning and metacognition?
}

\author{
Lee FitzGerald \\ School of Information Studies \\ Charles Sturt University \\ Locked Bag 588 \\ Wagga Wagga, NSW. 2678 \\ Australia \\ lefitzgerald@csu.edu.au
}

\begin{abstract}
Research carried out at Loreto Kirribilli, a Catholic independent secondary school in Sydney, Australia, in 2014 demonstrates that Guided Inquiry scaffolding enhances learning and metacognition. Students undertaking the Historical Investigation in Year 11 develop an interest in an area of Ancient or Modern history, explore it, develop an inquiry question, and answer it in an essay. The Ancient History class was scaffolded by Guided Inquiry curriculum design and support, while the Modern History class conducted their investigation independently. Deep learning was evident in the questions asked and the answers written in the Ancient History essays. There is evidence of a difference in quality in the questions asked and answered by Modern Historians. It would appear that the scaffolding of Guided Inquiry has enhanced learning, while recognizing the effect an excellent teacher has on already high achieving students. Ancient history students also demonstrated a high level of metacognition in their reflections.
\end{abstract}

Keywords: Guided Inquiry; Information Search Process; Guided Inquiry Design Process; metacognition

\section{What is Guided Inquiry (GI)?}

"Gl is a way of thinking, learning and teaching that changes the culture of the classroom into a collaborative inquiry community." (Kuhltau, Maniotes, Caspari, 2012)

It is an emerging pedagogy said to produce deep learning by its focus on the Information Search Process (ISP), the autonomy of students in finding and answering their own inquiry question, its focus on working in groups (inquiry circles), and its ongoing support for students from teachers and teacher librarians (TLs).

To thrive as $21^{\text {st }}$ century learners, students must be able to judge the quality of information, find a way through complex and disparate information, formulate their own focus and answers to their own questions, and transform information into knowledge. They need to be agile, critical thinkers who are digitally fluent, able to read complex texts and write clearly. 
They need to come up with creative solutions to problems they identify and to learn the skills of working in teams. These are the skills of the $21^{\text {st }}$ century worker, and they are synonymous with the skills of $\mathrm{Gl}$.

In a time of global curriculum reform, there is a move to inquiry learning across education systems in many countries. Since Peter Drucker's (1992) work on knowledge workers, there has been a slow move towards at least enriching the industrial model of education (Robinson, 2010), in favor of education systems which produce people who can think creatively, research effectively, problem solve, and work in teams. Across the globe, education systems are reforming in favor of $21^{\text {st }}$ century skills. Definition and promotion of these are the subject of close attention (Abbott, 2014; ATC21S, 2012; EE Explore America, 2012; GELP, 2012; P21, nd; Responsible subversives, 2011).

Common to taxonomies of $21^{\text {st }}$ century skills are these: Creativity, innovation, critical thinking, problem-solving, decision-making, Learning to learn/metacognition, Information literacy, ICT literacy, communication, collaboration, citizenship and responsibility. These are the central concerns of $\mathrm{Gl}$.

\section{Central elements of GI}

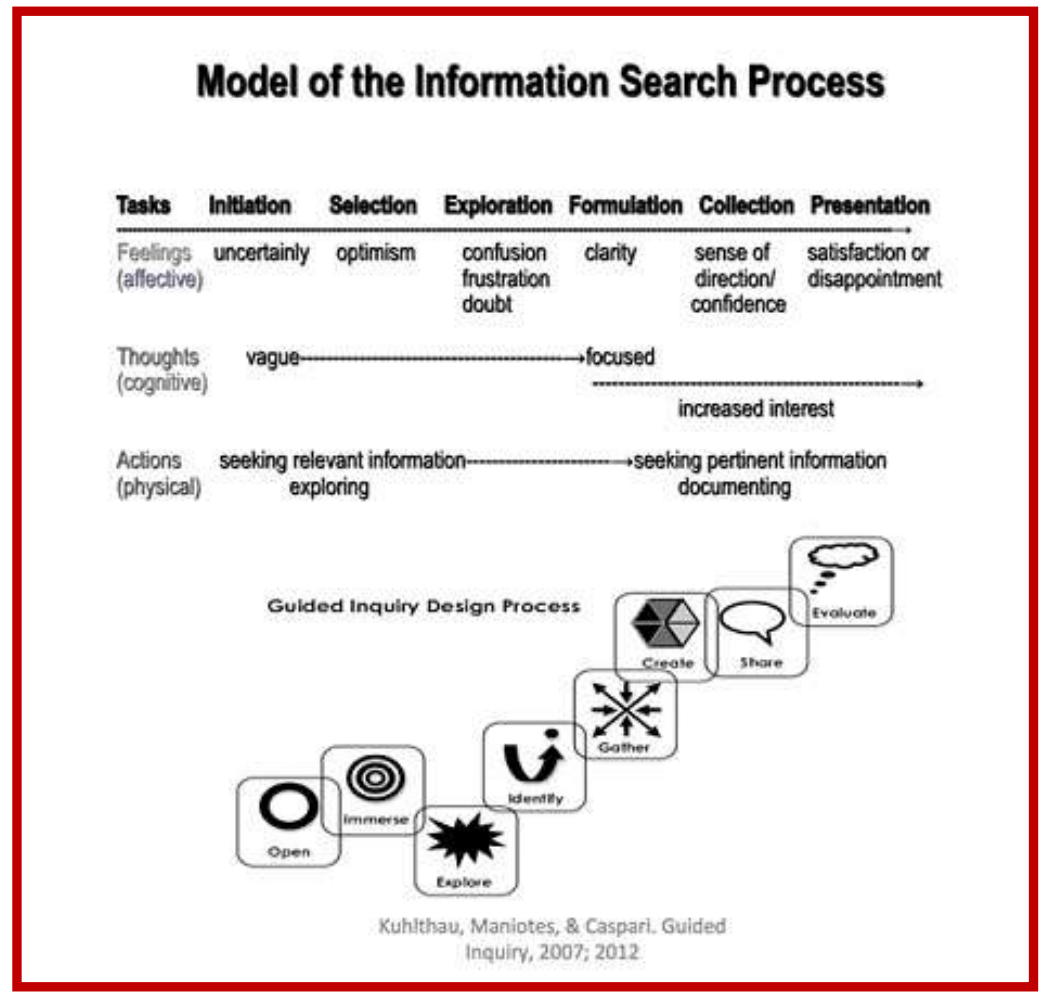

Figure 1: Model of the Information Search Process and the Guided Inquiry Design Process (Kuhlthau, 2012)

The ISP is the central concept of GI. New to Gl is the Guided Inquiry Design Process (GID), with the two processes sitting side by side. The ISP describes what students do when they 
research; and the GID process is what the inquiry community (the class) is doing. It is evident from the stages of the ISP in the diagram above that it takes time to develop the personal engagement characteristic of deep learning. Also the ISP suggests that there are times of information overload and stress during a researcher's journey from curiosity to knowledge.

At the bottom of Figure 1 is the GID process. This is intended to be used by teaching teams to:

- create the unit of work

- set the task in its stages

- use a shorthand for all students to use for the stage they are up to.

- schedule the task

- teach the skills required at each phase

- describe what the Inquiry community (class) is doing at any given point.

Guided Inquiry design: A framework for inquiry in your school (Caspari, Kuhlthau and Maniotes, 2012) (GIDF) has made the operation of a GI quite concrete. The book presents a highly structured approach to GID, and looks in detail at central concepts, such as

- Collaboration of the instructional team guiding the inquiry - the roles of each member in each part of the process from design, to implementation, to assessment.

- Third space: bringing the world of the student (first space), the world of curriculum (second space) into a third space where students can construct world views of their own.

- Whole units delivered by inquiry - where there is minimal teaching and the emphasis is on learning taking place by inquiry with teacher and TL facilitators.

- Inquiry community and Inquiry circles - The whole class group is the Inquiry community. Inquiry circles can be used in curriculum areas which might benefit from dividing up the work into perspectives. Inquiry circles are useful for students working together on inquiry skills.

- 6C's: Collaboration, Conversation, Composition, Choosing, Charting, and Continuing - These are the six elements of a Gl - the six skills necessary to its continuance.

- Journals, logs and inquiry charts - Throughout a GI, students keep notes, record logs of their bibliographic processes, and at the Collect/Create and Present phases, use inquiry charts and mind maps to synthesize their information.

- Continuous reflection and feedback - A hallmark of a Gl is reflection. This can be a formal reflection and/or conversation between student and the teaching team. Reflections can be used to gather data for evidence-based practice.

- Culmination conversation - There is a formal agenda in GIDF for the teaching team to use at the conclusion of an inquiry unit. It allows for discussion on the achievements or otherwise of individual students. It also allows for discussion of interventions that worked, those that didn't, and changes that might be needed.

In some schools, the idea of a culmination conversation has become a part of what's expected of students, as well as the teaching team, at the end of an inquiry unit. Students are given five minutes to think about a higher order question arising from their area of study, but not the same as their inquiry question, and then speak for 2 minutes on it, with the rest of 
the inquiry community listening. The culmination conversations for students make clear that the level of engagement a GI demands pays off in terms of deep learning, critical thinking and commitment.

\section{Literature review}

Professor Carol Collier Kuhlthau's observations of how people of all ages feel, think and act when they are doing a research task have spanned multiple studies over the last three decades. The original study can be found in Kuhlthau (1989) and a comprehensive re-visiting of the ISP was carried out in 2008 (Kuhlthau, Heinstrom \&Todd). This study showed the model to be as relevant as ever, especially in the digital environment. Other studies by Kuhlthau confirmed the ISP as an observed model of how people research (Kulthau 1988a, 1988b, 1989, 1991).

The theory and practice of $\mathrm{Gl}$ has burgeoned over the last 10 years in the publication of three books on Guided Inquiry, which are practical approaches to its implementation - (Kuhlthau 2004; Kuhlthau, Maniotes \& Caspari,2007 and 2012). Alongside this, evidence based practice has become very much part of what TLs need to do to demonstrate the difference they make to student learning. (Gordon 2009a and 2009b; Gordon \& Todd 2009; Todd 2011b, 2012a and 2012b). The School Library Impact Measure (SLIM) (Todd, Kuhlthau \& Heinstrom, 2005) was devised for practitioner's use in schools, and has been used by TLs, especially in Australia. (Todd, 2011 and 2012a).

The combination of the developing theory and practice of $\mathrm{Gl}$, and the need for evidence based practice has led to practitioner articles about GI and the use of SLIM to demonstrate achievement of learning outcomes, for example FitzGerald (2011), Scheffers (2008) and Sheerman (2011).

There have been studies carried out by academics in schools to demonstrate the impact of GI on student learning as well. (Harada, 2002; Todd, 2006; Kim \& Todd, 2008; Todd, 2010). And academics have written in practitioner journals to spread the word about evidence based practice and GI (Todd 2011a; Hay \& Todd 2010; Todd 2011b, 2012a and 2012b).

There was an opportunity offered by the 2014 historical investigations at Loreto Kirribilli to use the new scaffolding of GI (Kuhlthau, Maniotes \& Caspari, 2012), elements of SLIM (Todd, Kuhthau \&Heinstrom, 2005), and other data to investigate whether students with the benefit of this support fared better in their growth to deep learning than students not so supported.

\section{Research aim}

My aim was to find out if the scaffoldings of $\mathrm{Gl}$ assisted in both the development of deep learning and awareness of the process of learning and to answer my research question: Does $\mathrm{Gl}$ enhance learning and metacognition?

\section{Context/participants}

History students at Loreto Kirribilli, a Catholic independent school in Sydney, Australia, undertook an historical investigation in 2014, with one class conducting their investigation using GI methods and scaffolding, while the other two classes had scaffolding of a moderate level. The class that was scaffolded with GI was Ancient History, and the two classes that were not so scaffolded were Modern History. 
The Year 11 Historical Investigation was chosen as the area of research, because it is possibly the only time in the History curriculum where students are free to identify, explore and make conclusions on an area of history, only restricted by time periods and whether or not the topic is one they have to study as part of their curriculum

The sample was 52 students in two modern history classes of 18 students each, and one Ancient history class of 16 students. The students are 16/17 years old, all capable, highly motivated students, who have never undertaken a long term inquiry project before. Their teachers and TLs are dedicated, talented teachers.

\section{Control group issues}

It was intended that the control group of two Modern History classes would take exactly the same survey questions. But it turned out for reasons beyond the researcher's control that the only valid responses were for Question 5 and for Question 6, and from one class only.

\section{What did the GI entail?}

The inquiry task in each class was effectively the same - Choose an area of Modern/Ancient history, create a question and answer it in an essay.

\section{What was the same for both Modern and Ancient History?}

\section{Each class had:}

- active support and feedback from teachers throughout the process

- resourcing from the TL.

- teaching of how to use Easybib, (a bibliographic software), create footnotes and to use the PEEL(Point, Evidence, Explain, Link) essay writing technique

- similarly highly motivated and capable students

- a culmination conversation at the end of the unit.

\section{What was different in the Modern and Ancient investigations?}

- Ancient historians:

- were explicitly taught the use of GI and the ISP throughout, including different search techniques for different stages of the ISP.

- worked in inquiry circles, which categorized choices of topics, as well as providing peer support for information gathering and synthesizing.

- reflected daily, as well as using the SLIM toolkit, on the wiki created by the TL for the task.

- had TL support throughout.

- used the wiki to house the task, scaffolds, reflections and feedback.

- were taught how to use Questia (an online database) and Evernote, (a notetaking software and app) with feedback.

- were scaffolded explicitly on creating questions.

On all of the above points, modern historians had no input.

\section{The teaching team in the Gl}

The team of teacher and TLs for the Ancient History GI had the following responsibilities: 


\begin{tabular}{|l|l|}
\hline \multicolumn{1}{|c|}{ Teacher } & \multicolumn{1}{c|}{ Teacher librarians } \\
\hline $\begin{array}{l}\text { Introduced the Ancient Historical } \\
\text { Investigation }\end{array}$ & $\begin{array}{l}\text { Introduced Guided Inquiry and Information } \\
\text { Search Process }\end{array}$ \\
\hline $\begin{array}{l}\text { Scaffolded choice of topics into inquiry } \\
\text { circle areas }\end{array}$ & $\begin{array}{l}\text { Taught searching appropriately for each } \\
\text { stage of the process. } \\
\text { Provided sources throughout inquiry. }\end{array}$ \\
\hline Provided feedback on wiki & Set up and monitored wiki for reflection \\
\hline Worked with students on sources & Set up and provided feedback on Evernote \\
\hline $\begin{array}{l}\text { Marked the essay } \\
\text { Both: Attended each class, worked in inquiry circles, worked with students on a roster, } \\
\text { worked with students to develop inquiry questions, and attended culmination } \\
\text { conversations. The inquiry took 5 weeks, with 3 classes per week. }\end{array}$ \\
\hline
\end{tabular}

\section{Methodology}

The following data were gathered from both Modern and Ancient History students:

- Responses to the SLIM Toolkit (School Library Impact Measurement) (Todd, Kuhlthau \& Heinstrom, 2005)

- Essays written by students, including comparison of questions between Ancient and Modern historians.

- Marks given to students for their essays and for their process.

A final reflection was asked of the Ancient historians only: Describe your feelings as you progressed through the stages of the Information Search process.

These are the questions in the SLIM Toolkit:

Q1: Take some time to think about your topic. Now write down what you know about it.

Q2: How interested are you in this topic? Not at all/Not much/Quite a bit/A great deal

Q3: How much do you know about this topic? Nothing/ Not much/Quite a bit/A great deal.

Q4: When you do research, what do you generally find easy to do?

Q5: When you do research, what do you generally find difficult to do?

Q6: What did you learn in doing this research project?

This instrument has been used in frequent practitioner and professional research. The questions were presented to students at Open, Identify, and Create/share stages of the task, except the last question, offered once at the end. 


\section{Findings}

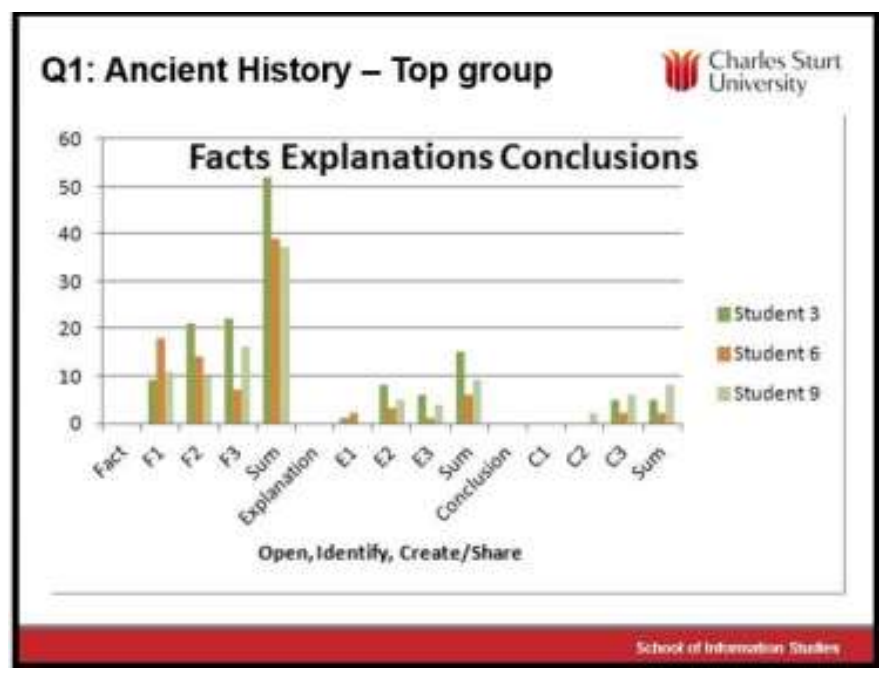

\section{Question 1:}

Take some time to think about your topic. Now write down what you know about it.

This is the question with the potential to answer the first part of the research question: Does GI enhance learning? Analysis involves tabulating each response as to whether they are facts, explanations and conclusions. Typically students will have a lot of facts at Open. It is hoped they will begin to add to the facts with explanations and conclusions as their knowledge and commitment to the topic grows. The underlying thesis is that students allowed to follow their own interest and given time to do so, will develop deep learning, as evidenced by the growing number of explanations and conclusions.

From Question 1, ideally there should be a movement from many facts at the beginning, diminishing at the second and third collection points into a smaller but clear growth of explanations and conclusions. This is evident here.

This graph shows three students in the top range (for essay and process marks) and the number of facts, explanations and conclusions they had at the three gathering points.

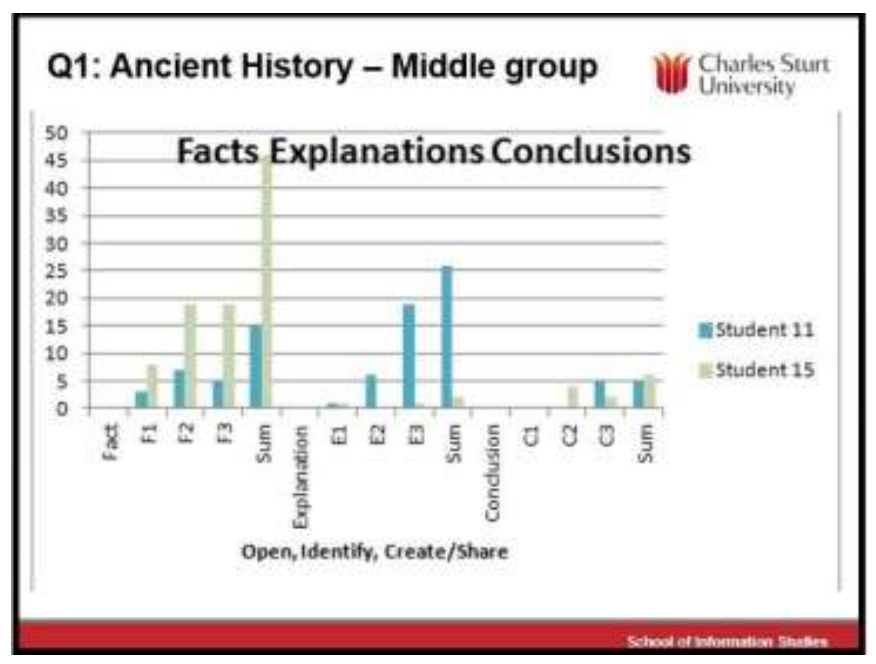


This graph shows three students in the mid-range for process and essay marks and the number of facts, explanations and conclusions they had at the three gathering points.

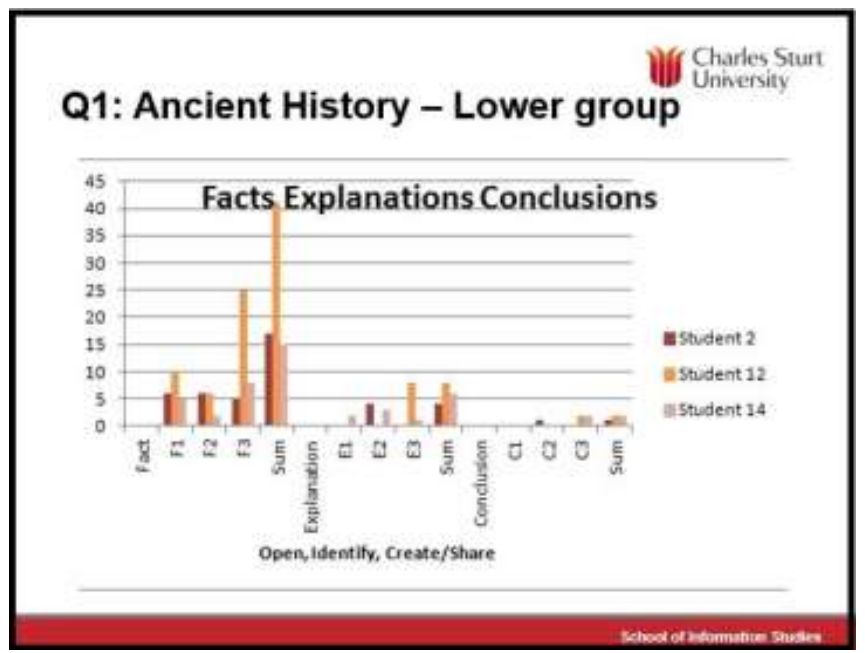

These students, who scored in the lower range on their essays and process marks nonetheless show a growth from facts to explanations, while they show less movement to conclusions than the other two groups.

All students showed a growth indicative of the processing of information from facts, through explanations, to conclusions - thus demonstrating a clear growth towards deep knowledge.

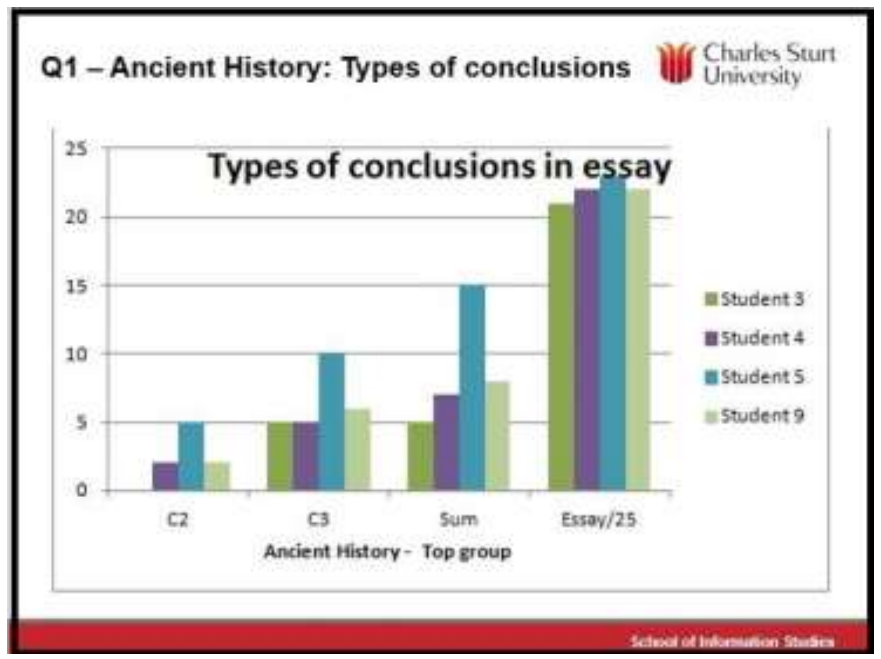

Analysis of Question 1 caused the researcher to consider types of conclusions and if there were differentiations to be made on the kinds of conclusions students use. Analysis of the essays of these students demonstrated that though there were many conclusions, they were of distinctly different quality. A differentiation was made on the following basis:

C - Straightforward expression of conclusion, no justification or elaboration

C2 - Conclusion contains 1 justification or elaboration

C3 - Conclusion contains more than 1 justification or elaboration.

An analysis of the top ranked students' essays demonstrated that: 
- they had a uniform number of conclusions in their essays.

- they had no $\mathrm{C}$ conclusions.

- their conclusions included a substantial number of the richer kind of conclusions.

This pattern was generally not repeated in the lower marked students, who had mostly straightforward conclusions.

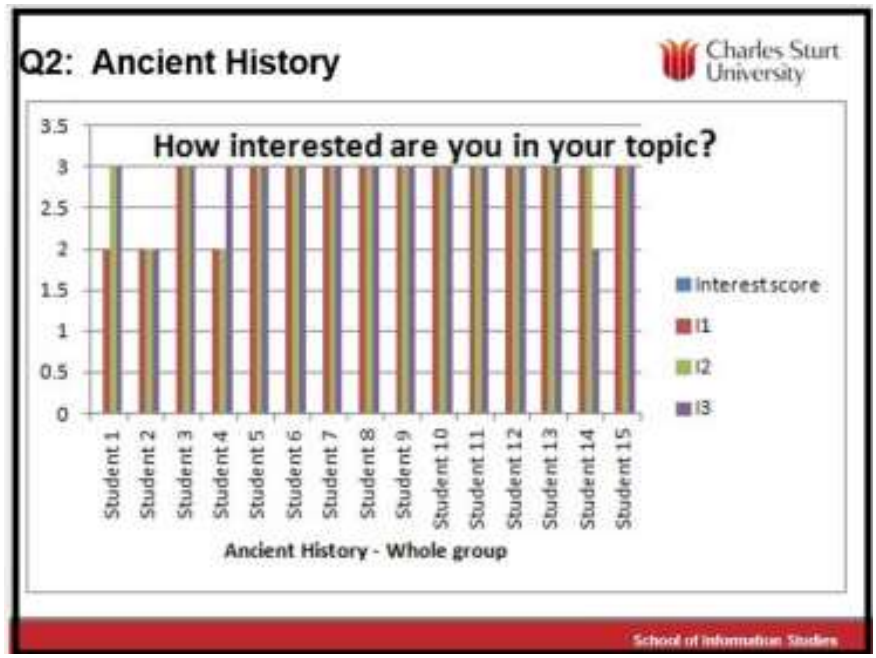

\section{Question 2:}

How interested are you in your topic?

This question was given to students at Open, Identify, Create/Share parts of the process. They could choose not at all, not much, quite a bit, a great deal. This is an excellent finding, as it shows a majority of students expressing unwavering interest throughout the project.

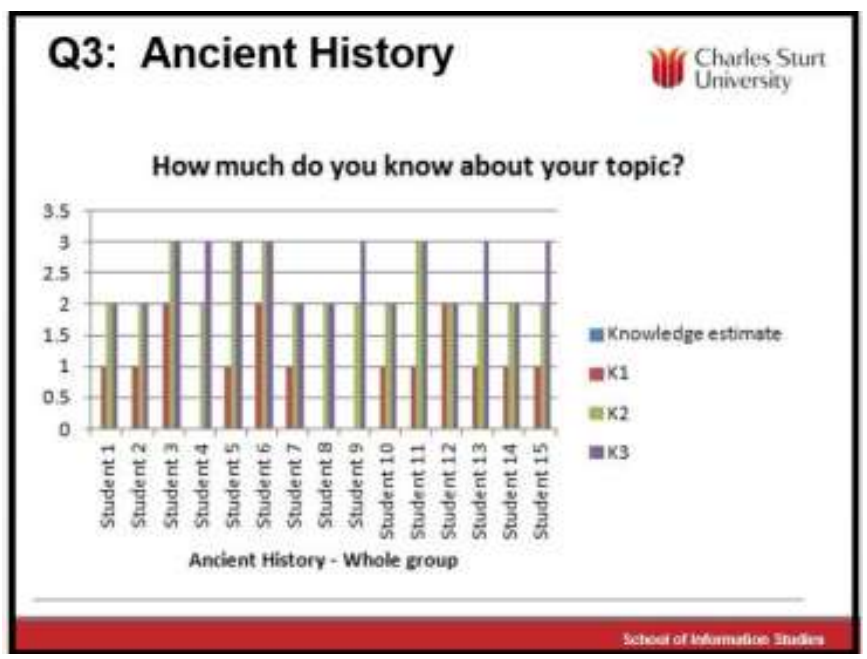

\section{Question 3:}

How much do you know about your topic?

This response shows student self-judgment on how much they know about their topic, collected at the three gathering points for the survey. They could choose nothing, a bit, quite 
a bit, a great deal. Most started at knowing nothing and moved to quite a bit. Some judged themselves by the end of the project as knowing a great deal.

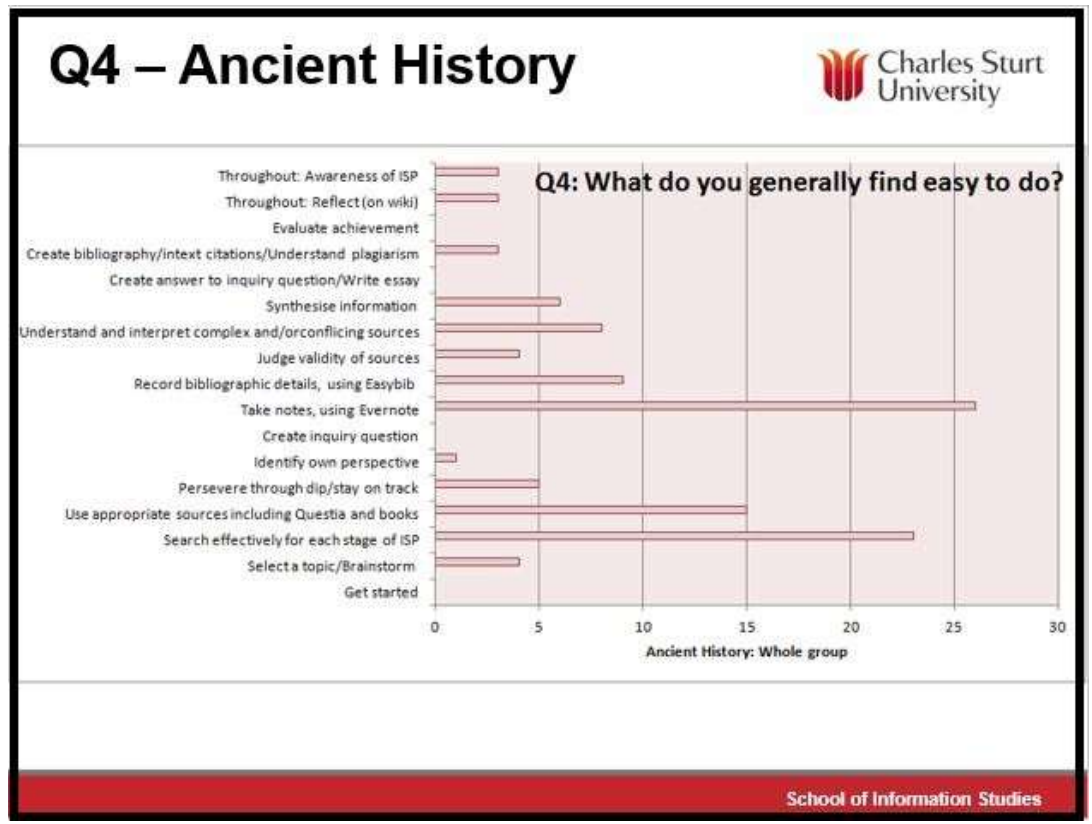

\section{Question 4:}

What do you generally find easy to do?

This was administered at Open/ldentify/Create and Share. Of interest is the fact that the two things students say they could do best are Take notes using Evernotes, and Search effectively for each stage of the ISP. However, the affirmation for taking notes and searching effectively for the stage of ISP may be as a result of the focus on these two elements of the GI. It is interesting too that nobody thought it was easy to create an inquiry question, or to answer it.

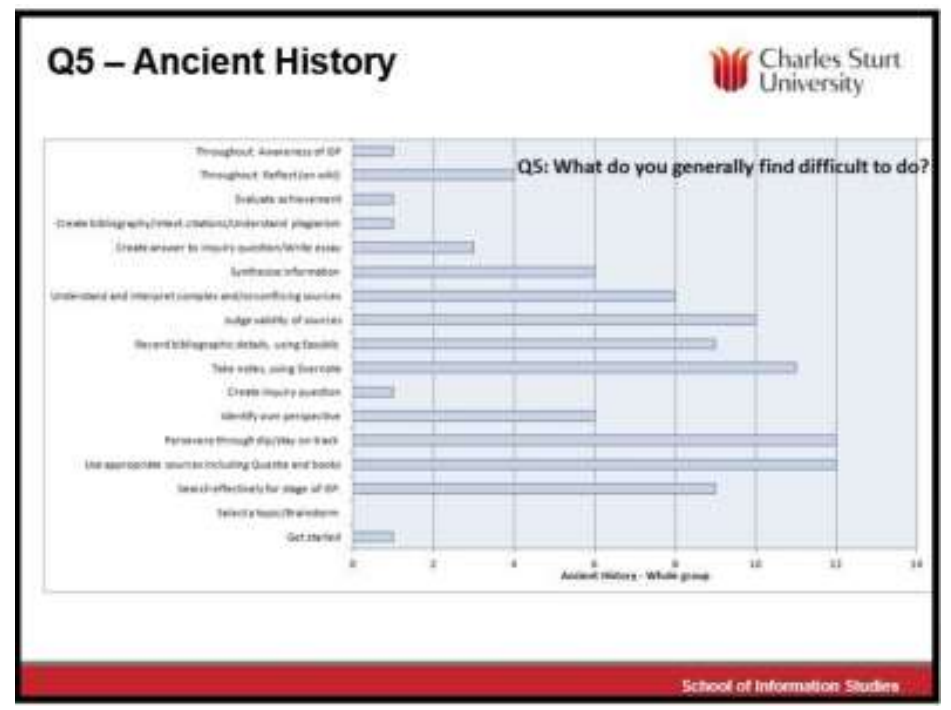




\section{Question 5:}

What do you generally find difficult to do?

This and Question 6 are the only ones that the researcher was able to gather data from both classes for, owing to circumstances in the school beyond her control.

The Ancient historians show an interesting range of difficulties here. They could articulate that it is difficult to persevere through the dip of confidence that comes in the ISP at Immerse, and to stay on track, and to search effectively for the stage of the ISP. Their awareness of the process of research was articulated, showing that students have gained some facility with the ISP. They also report that they find it difficult to use complex sources.

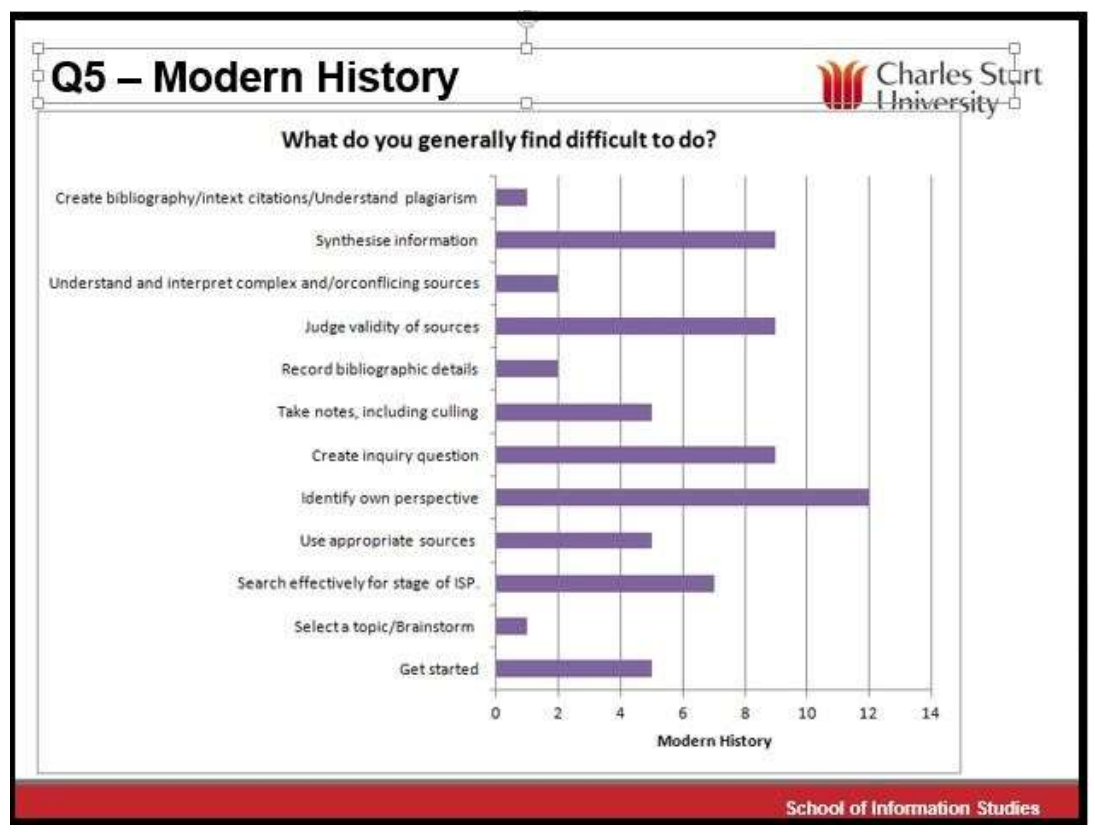

The Modern History group did not have the ISP outlined to them, and their reported difficulties are noticeably different from the Ancient History group. It is interesting that a significant number did not know how to get started. Identifying their own perspective was the greatest difficulty they had, followed by equally, stay on track, use appropriate sources, and synthesize information. They did not refer to reflecting on their process, and in the "other" category were three responses saying I don't know how to start my investigation, and I need a more structured approach to my investigation. 


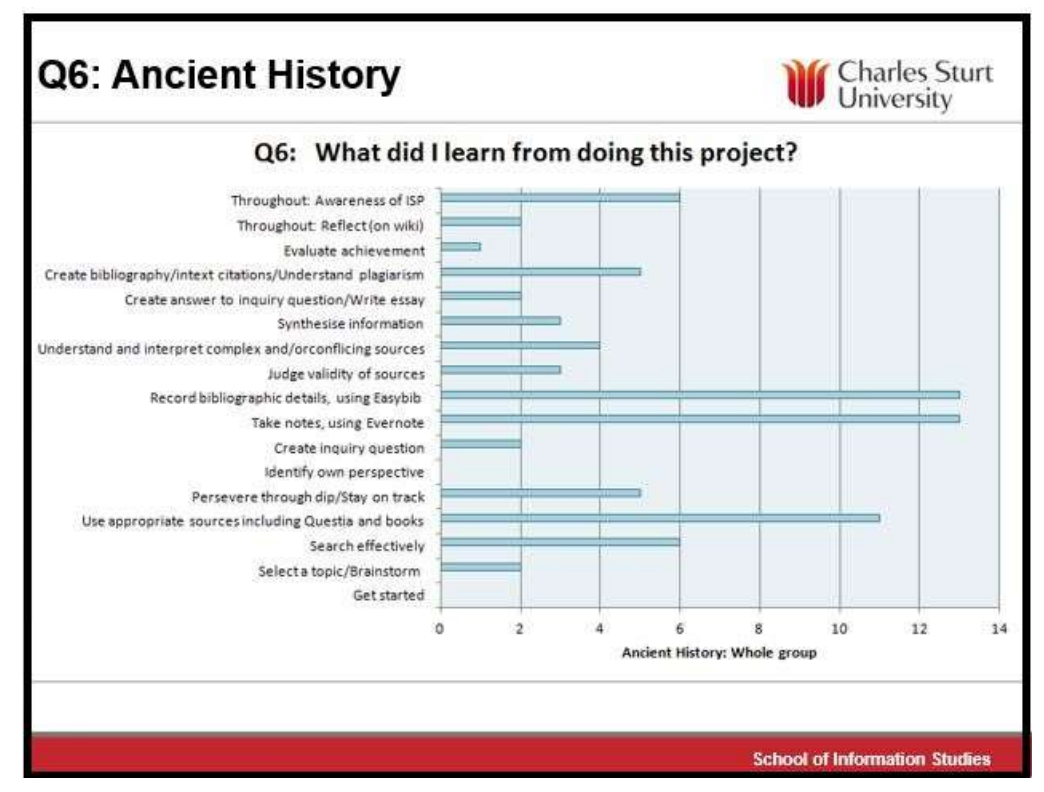

\section{Question 6:}

What did I learn from doing this project?

Ancient Historians learnt some of the same concrete tasks as the Modern historians, i.e. to use Easybib, and to do footnotes. Ancient historians highlight that they learnt to take notes using Evernote, indicate a high level of awareness of the ISP, and the graph shows that they learnt how to use appropriate sources as their biggest learning.

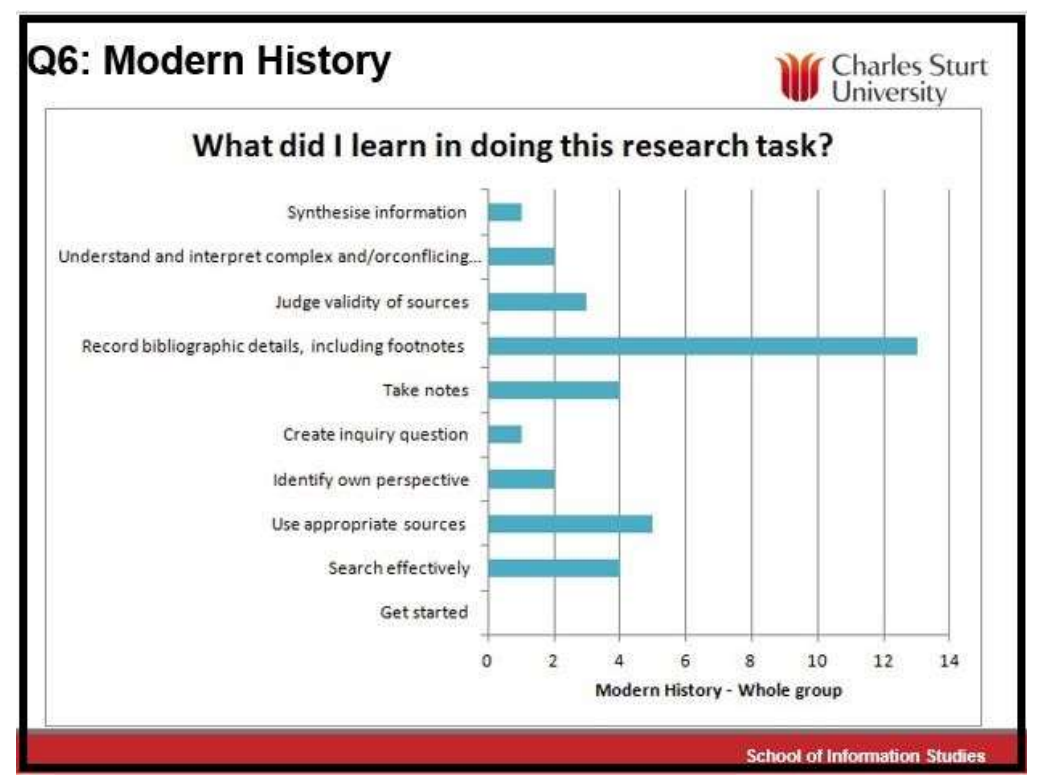

Modern historians' most often expressed learning was recording bibliographic details, which included footnoting. There is no awareness of the ISP. 


\section{Summary of findings from the SLIM questions}

Questions 1-4 were taken by the Ancient History class only, due to difficulties with the administration of the survey for Modern History.

Q1: Take some time to think about your topic. What do you now know about it? The growth from facts to explanations to conclusions in the reflection sheets and in the essays does demonstrate a growth to deep knowledge. Every Ancient history student was able to take the movement from large numbers of facts, through explanations, to variable numbers of conclusions. But conclude they all did. Some of this movement can be attributed to the quality of the teaching they had, and their intrinsic motivation as highly achieving students at a highly achieving school, some to the scaffolding provided by GI.

The Culmination Conversation also demonstrated the growth of deep knowledge, as students were able to express knowledge about historical ideas relating to their content area very clearly and at some depth.

\section{Q2: How interested are you in this topic?}

Ancient historians all maintained a high level of interest in the project throughout.

Q3: How much do you know about this topic?

Ancient history students' self-reported knowledge grew from Response 1 to Response 3

\section{Q4: When you do research, what do you generally find easy to do?}

The most frequently mentioned items were take notes, and search effectively for the stage of the ISP.

\section{Q5 and Q6: taken by both classes.}

Q5: When you do research, what do you generally find difficult to do?

Persevering and using complex sources were the most mentioned by Ancient historians Getting started, identifying own perspective, persevering, using appropriate sources, synthesizing information were the most mentioned by Modern historians.

\section{Q6: What did you learn in doing this research project?}

Both groups learnt the same concrete tasks, Use Easybib and how to do footnotes. Ancient historians also learnt how to search differently for the stage of the ISP concerned, use Evernote for notetaking, and Questia for deeper reading at Explore. Ancient historians demonstrated a strong awareness of ISP, while Modern historians had no awareness of an information process. 
Other data - Essay questions

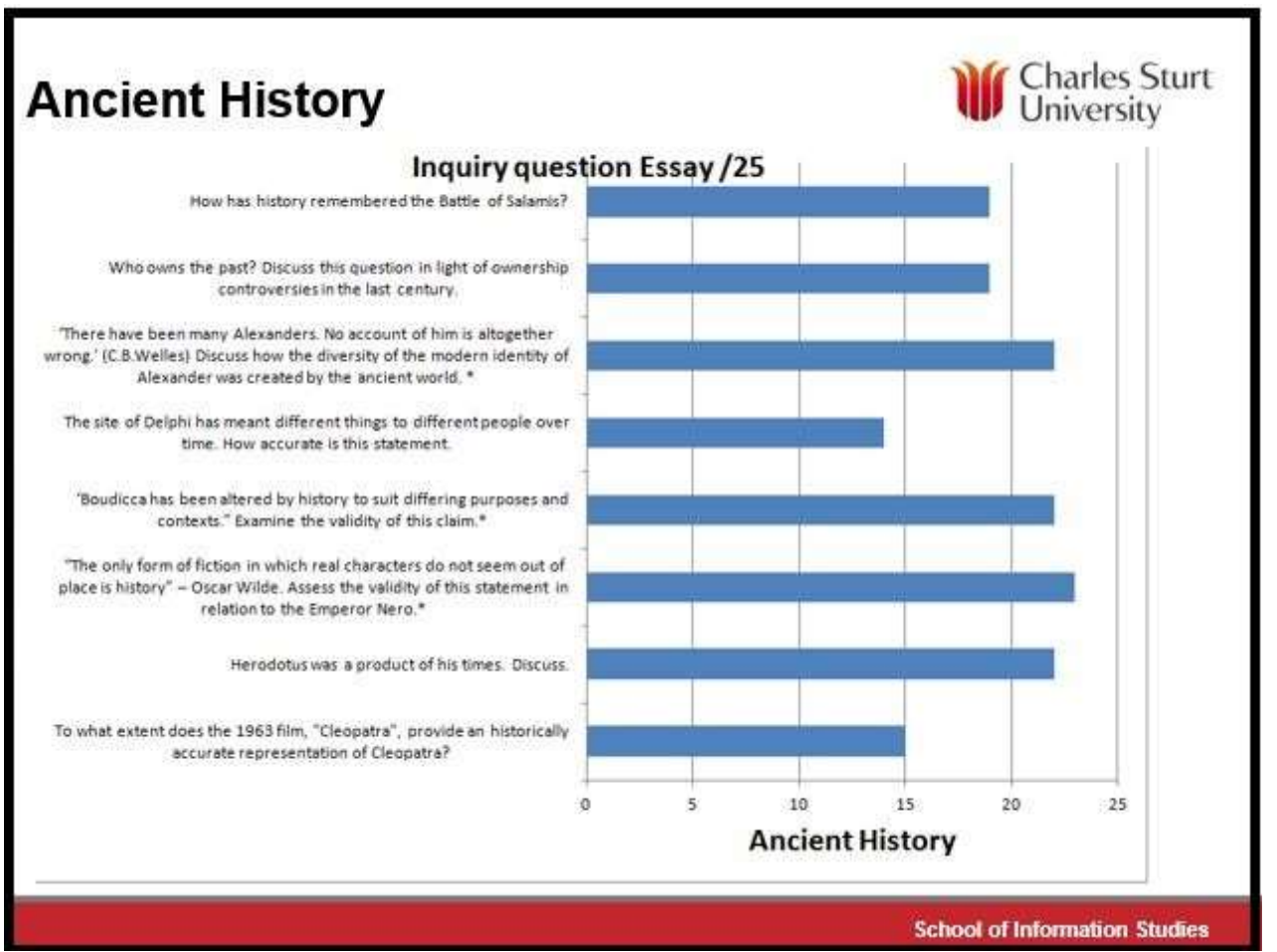

This is a range of Ancient Historians' essay questions and the mark assigned to them $/ 25$.

Of note is the higher order nature of the questions, the use of quotes to frame the question. Note also, that even the highest achieving students did not achieve full marks. This could be explained by a more rigorous process of marking in Ancient History. 


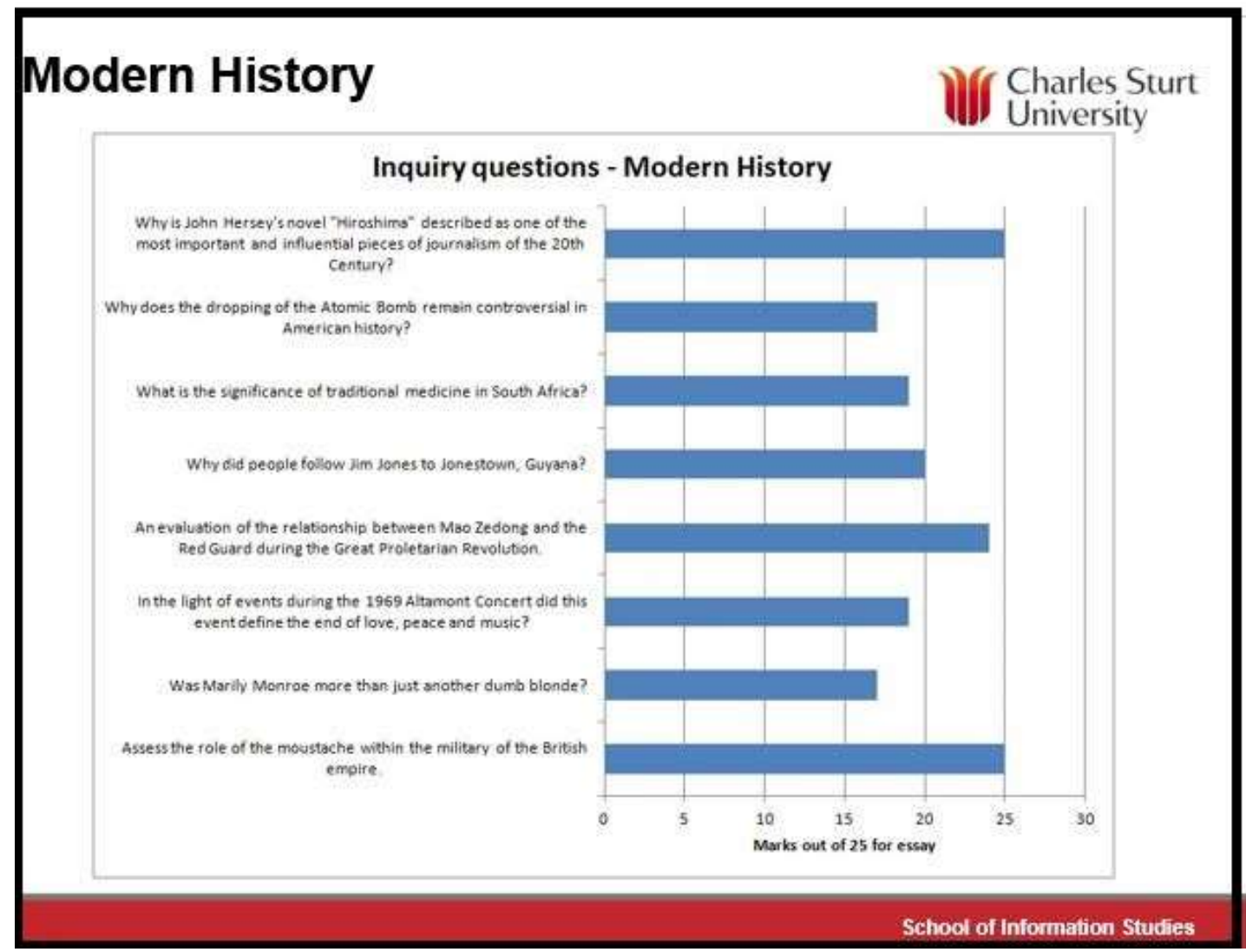

This is a range of Modern Historians' essay questions and the mark assigned to them $/ 25$.

A clear difference from Ancient history questions is not using quotes to frame a question and a wider approach to what makes history. Questions are much more straightforward than their Ancient history counterparts. Specific guidance in creating questions was given to the Ancient historians. 


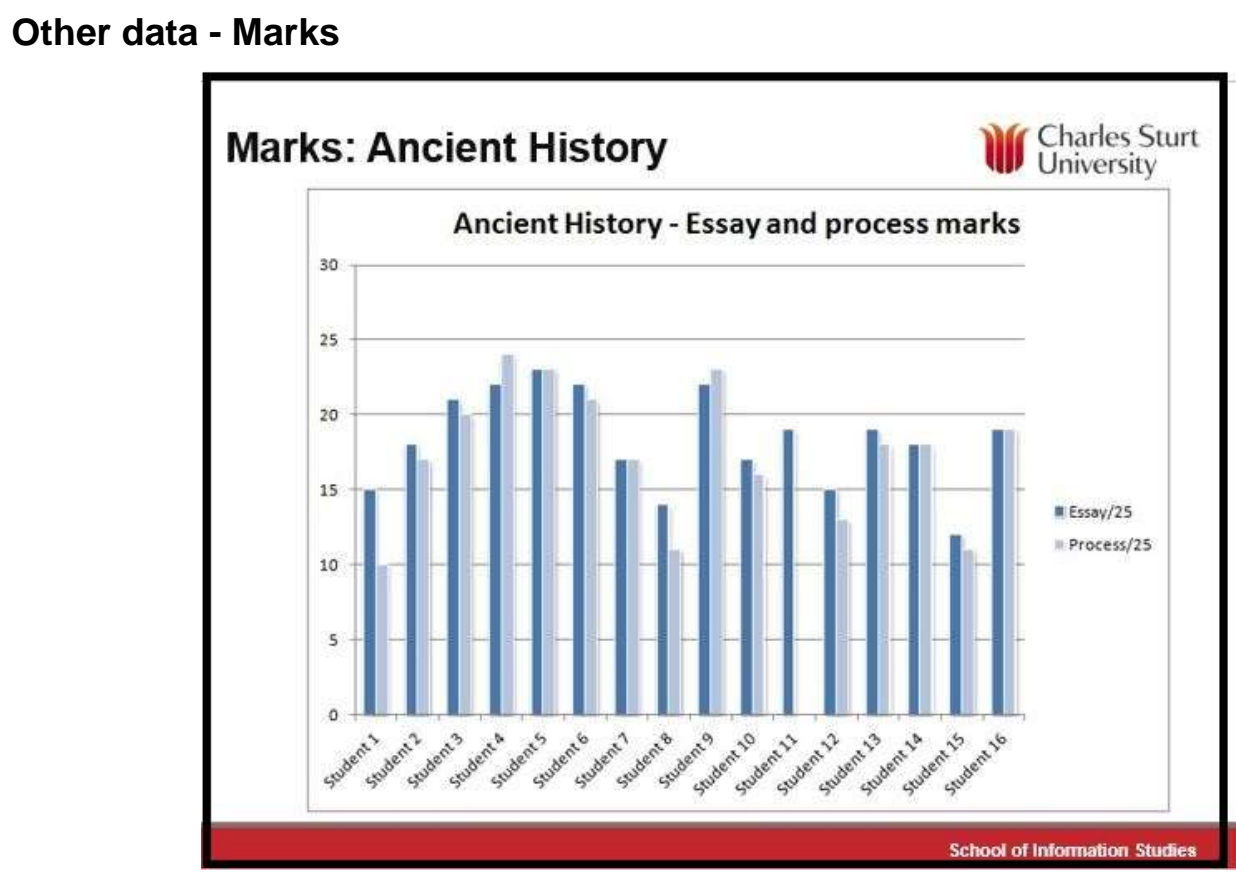

Ancient historians' process and essay marks show some alignment between process and essay, especially the top rangers, 4, 5, 9 and 16. The graph shows lower marked students having correspondingly lower process grades: $1,2,8$. Other factors, as in student 1 , where her process was haphazard, but her essay quite good, can be accounted for with good writing skills, and/or a good question.

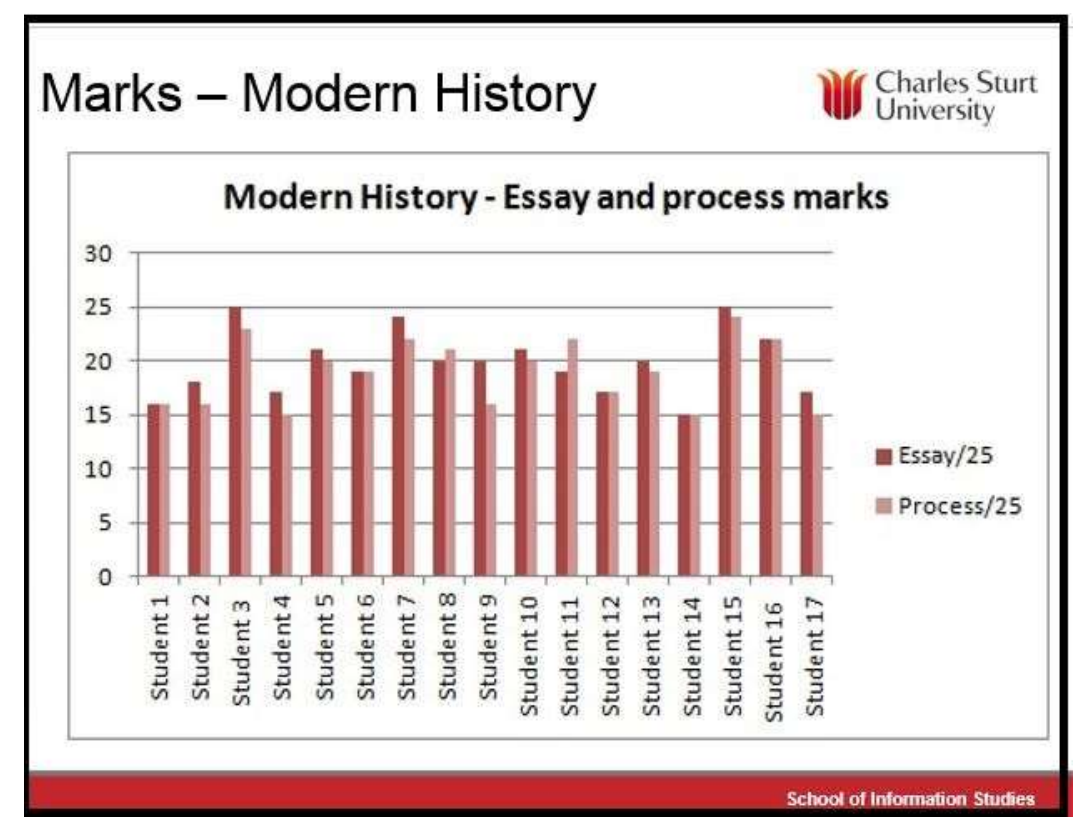

In the Modern History project, teachers did both process and product marking. There was no TL involvement in the marking. There were considerably less steps expected in the process 
and this may account for the closer alignment between process and product than appears in the Ancient marks, where process was marked by TL and product was marked by teacher. The marks awarded for essays in the top range are higher than in Ancient. This could be because of differences in teacher marking expectations and better writing in some of the Modern students.

\section{Other data: Reflections - Describe your feelings as you progressed through the stages of the Information Search process.}

Following are reflections gathered from the final reflection, administered to the Ancient historians only. They show more than any of the graphs the level of involvement in learning students had, and the quality of their metacognition. They show a definite yes to both parts of the research question: Does GI enhance learning and metacognition?

Open

I liked that we were also given complete freedom to choose what we liked, that way it was ensured that we were doing something that we found interesting, rather than something that was assigned...

\section{Immerse}

The Sea people were so fascinating to me and I couldn't wait to immerse myself in information about them. But I made sure to keep to overview information and not to immerse myself too greatly...

The true honeymoon stage! Basking in my decision to focus on Emperor Nero, I pursued various online encyclopedias and websites and watched as many YouTube videos as I could, .his was a great way to absorb information quickly whilst being entertained, and gave me a fantastic overview basis to envisage the path for exploration...

\section{Explore}

This was the fun part of the assignment, where there was no imposed time limit on you or any sort of expectation/pressure (yet). I could actually just sit there hours on end just reading information about the Sea Peoples...

There was so much information! I did fall into a dip, in which I wished to change my topic as I felt that there was nothing controversial about Herodotus..

Identify

At this point it was clear that my area of interest was in how history had shaped the various portrayals of Alexander through time and the implications of this for our modern idea of who the ancient personality was..

I found this part quite challenging as it was really hard to narrow my choices down. But with the help of my teacher and TL, it was easier for me to decide on my focus area..

\section{Gather}

When it was time to start gathering relevant information was when I had the most challenges in my research process. . I found it extremely tedious and time consuming. This stage really required active learning, and persistence... 


\section{Create/Share}

For me, the most challenging part of this whole process was the essay. I had talked over my mind map with my teacher, which definitely helped the whole process and I had a definite idea of where my essay was going however getting all my ideas out of my head and onto paper was harder than anticipated. At this point I was feeling frustrated, and I just wanted the whole process to be over...

\section{Evaluate}

Throughout this whole topic I have had the chance to evaluate my research skills. The daily logs have been good in a sense as they have structured my reflection and given me key goals to complete both short term and long term. The weekly reflections have helped me to gauge the progression of my researching skills and have targeted particular aspects of my research which I have needed to keep up to date, such as Easybib...

\section{Conclusions}

\section{Does Gl enhance learning and metacognition?}

It would appear that the scaffolding provided to Ancient history students did enhance learning and metacognition, as evident from the data showed in this paper. There are other reasons for the achievements of these students - they are motivated, high achievers, often with strong writing skills. They have very experienced and dedicated teachers. Achievements of the Modern historians without the benefit of Gl scaffolding show that there are other factors at play, such as those mentioned already. However, there are definite differences in the quality of the questions posed by the two groups, and it is also clear that the Ancient historians became adept at recognizing the stage of the ISP they were experiencing, and their reflections show this. They learnt how to manage their information process, and what to expect whenever they do research, e.g. The Dip - that loss of confidence expected at Explore in the ISP.

Reading complex sources is anecdotally the greatest difficulty both groups had - they resist it. As well, there were issues with creating an inquiry question - Modern historians said they found it difficult, Ancient historians wanted to create it too early.

In conclusion, it would appear that teaching/providing students with the scaffolding of GI and the ISP has enhanced their learning and metacognition.

\section{Implications for practice}

Some broad generalizations about using GI in schools might be developed from this research, and the myriad other studies in this area, mentioned in the Literature review. They are:

- Teach students the ISP and help them practice using it - from as early as Year 5. The earlier students realize that their information seeking and using behavior follows the same process every time they have an assignment, if they are doing it with engagement, is a valuable support for learning.

- Allow students to choose their own area of interest and to develop their own questions as often as it is feasible, as this is at the heart of $\mathrm{Gl}$, and inquiry learning, which is so favored in curriculum documents in Australia and elsewhere.

- Expect TLs to-co plan, co-teach and co-assess research tasks. They are teaching partners in the inquiry curriculum of the school. 
- Make TLs responsible for information literacy skills, and for the school's achievement of the Critical and Creative Thinking General Capability (CCT) in the Australian curriculum, by building process steps into the grading of any inquiry task.

- Teach students how to search appropriately for the stage of the ISP they are at. Essentially this is to avoid information overload at Explore, to keep the search general then, in order to gather a notion of the scope of the topic. It's also to search deeply at Gather, when pertinent information is the key, rather than just relevant.

- Teach students how to create inquiry questions, and specifically not to create them too early. Use scaffolding provided by such techniques as Question Focus Formulation (Rothstein \& Santana, 2011)

- Consider whether active teaching on coming to rich, substantiated conclusions where the conclusion is substantiated is necessary.

- Look at how (if?) students are reading non-fiction texts and provide scaffolding from early years.

The last word is from a student, demonstrating the excitement of learning, through Gl:

Without realizing it I have actually connected a few dots in my understanding of world history as Alexander's world is linked to the experiences of other people in history. It surprised me at how connected every event is despite seeming a long time ago. I'm very happy with my final essay.

\section{References}

Abbott, J. (2014) Battling for the soul of education: moving beyond school reform to educational transformation. Retrieved from:

http://www.battlingforthesoulofeducation.org/

ATC21S Assessment \& teaching of 21st century skills (2012): 21st Century skills. Retrieved from: http://www.atc21s.org/

Drucker, P. (1992) The new society of organisations. Harvard Business Review, Sep-Oct; 70(5):95-104.

EF Explore America (2012) What is $21^{\text {st }}$ Century education? Retrieved from: https://www.youtube.com/watch?v=Ax5cNlutAys

FitzGerald, L. (2011) The twin purposes of Guided Inquiry: guiding student inquiry and evidence based practice. Scan 30(1)

Global Education Leadership Programme (GELP) We wanted to talk about $21^{\text {st }}$ Century education. Retrieved from: https://vimeo.com/32674575

Gordon, C.A.(2009a) An emerging theory for evidence based information literacy instruction in school libraries, Part 1: Building a foundation. Evidence based library and information practice 4:2 
Gordon, C.A. (2009b) An emerging theory for evidence based information literacy instruction in school libraries, Part 2: Building a culture of inquiry. Evidence based library and information practice 4:3

Gordon, C.A. and Todd, R. J. (2009) Weaving evidence, reflection and action into the fabric of school librarianship. Evidence Based Library and Information Practice 4:2

Harada, Violet H. (2002). Personalizing the information search process: a case study of journal writing with elementary-age students. School Library Media Research, 5.

Hay, L. \& Todd, R.J. (2010). School libraries 21C: The conversation begins. Scan, 29(1), 3042

Kim, S.U. \& Todd, R.J. (2008) The information search process of English language learner (ELL) students in a Guided Inquiry Project: an in-depth case study of two Korean high school students in the United States. Information Research, Vol.13, No 4

Kuhlthau, C.C. (1988a) Longitudinal case studies of the information search process of users in libraries. Library and Information Science Research, 10, 257-304

Kuhlthau, C.C, (1988b) Perceptions of the information search process in libraries: a study of changes from high school through college. Information Processing and Management, 24, 419-427

Kuhlthau, C.C. (1989) The information search process of high-, middle- and low-achieving high school seniors. School Library Media Quarterly, 17, 224-226.

Kuhlthau, C.C. (1989) Information Search process: A summary of research and implications for school library media programs. School Library Media Quarterly, Volume 18, Number 1.

Kuhlthau, C.C. (2004) Seeking meaning: a process approach to library and information services. Westport CT: Libraries Unlimited

Kuhlthau, C.C., Maniotes, L.,and Caspari, A.(2007) Guided Inquiry: learning in the 21st Century. Santa Barbara, California, Libraries Unlimited.

Kulhtau, C.C., Heinstrom, J., and Todd, R. (2008) The Information Search process revisited: Is the model still useful? Information Research, Vol 13, No 4

Kuhlthau, C., Maniotes, L., and Caspari, A. (2012) Guided Inquiry design: a framework for inquiry in your school. Santa Barbara, California: Libraries Unlimited.

Partnerships for $21^{\text {st }}$ Century skills (nd), Framework for $21^{\text {st }}$ Century learning. Retrieved from: http://www.p21.org/about-us/p21-framework

Responsible subversives (2011) Born to learn. Retrieved from https://www.youtube.com/watch?v=falHoOEUFz0 
Rothstein, D and Santana, L. (2011) Make just one change - Teach students to ask their own questions, Harvard Education Press

RSA Animate - Robinson, K. (2010) Changing educational paradigms. Retrieved from https://www.youtube.com/watch?v=zDZFcDGpL4U\#aid=P8wNMEma2ng

Scheffers, J. (2008) Guided Inquiry: a learning journey. Scan 27 (4)

Sheerman, A, (2011) Accepting the challenge: evidence based practice at Broughton Anglican College. Scan 30 (2).

Todd, R. J. (2006). From information to knowledge: charting and measuring changes in students' knowledge of a curriculum topic. IR Information Research, 11 (4). Retrieved from: http://www.informationr.net/ir/11-4/paper264.html.

Todd, R. J., Kuhlthau, C.C. \& Heinstrom, J.E. (2005) School library impact measure (SLIM) Center for International Scholarship in School Libraries, Rutgers University. Retrieved from: http://cissl.rutgers.edu/images/stories/docs/slimtoolkit.pdf

Todd, R. J. (2010) Guided Inquiry: a framework for opening doors and opening minds through the school library (in Swedish) in Framsidan 1: Oppna Dorrar For Oppna Sinnen: Skolbiblioteken Och Framtiden, edited byFredrik Swedemyr. Gotebord, Sweden: Kultur I Vast Regionbiblioteket,

Todd, R.J. (2011a) Charting student learning through inquiry. School Library Monthly, Vol 28 (3) $p 5-8$.

Todd, R.J. (2011b) From literacy to inquiry: a holistic approach to literacy development in selected Australian Schools. IFLA 2011 Puerto Rico. Retrieved from http://conference.ifla.org/past-wlic/2011/114-todd-en.pdf

Todd, R. J. (2011c) One Common Goal: Student Learning. Evidence from New Jersey. Synergy $9(2)$.

Todd, R. J. (2012a) Visibility, Core Standards and the power of the story: creating a visible future for school libraries. Teacher Librarian, vol.38, 6, p8+

Todd, R. J. (2012b) School libraries as pedagogical centers. SCAN, vol 31, (3) p. 27-36

\section{Biographical note}

Qualifications:

Sydney University: B.A. Dip. Ed. (English and Modern History)

UTS, Sydney: Graduate Diploma in Library Science

Australian Catholic University: Master of Education (Curriculum)

Lee FitzGerald joined Charles Sturt University School of Information Studies in January, 2014, following a long career as a teacher librarian in school libraries. She has a passion for 
teacher librarianship and the burgeoning theory and practice of Guided Inquiry. Her research interest is to confirm the growth of deep learning through inquiry, as well as the transferability of the process from one subject area to another, which she is investigating with Dr. Kasey Garrison. He book for ABC Clio in the Guided Inquiry series, tentatively entitled:

Implementing Guided Inquiry in a time of Global Curriculum Reform is due for publication in 2016. 